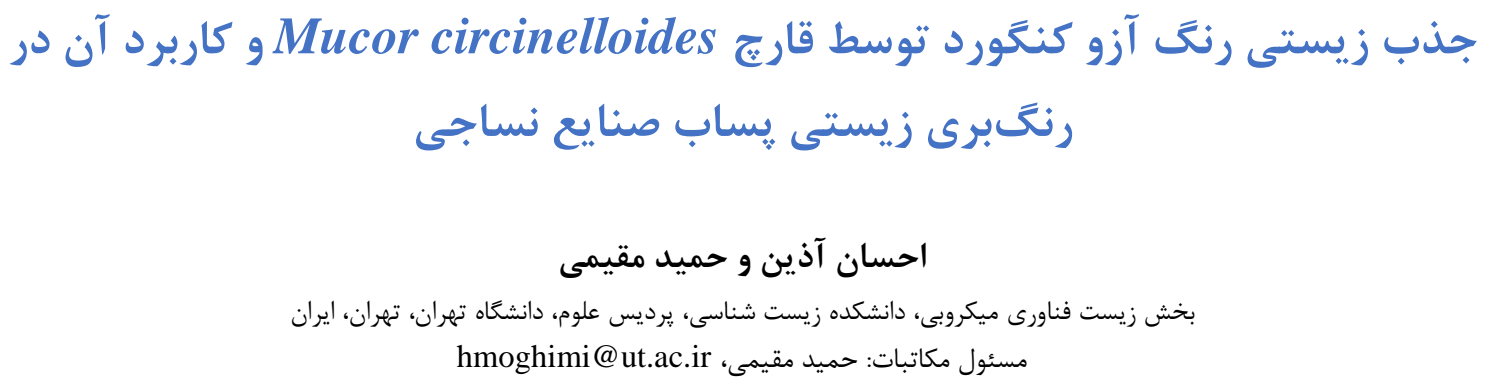

\title{
The biosorption of Congo red azo dye by fungus Mucor circinelloides and its application in the decolorization of textile industry wastewater
}

\author{
Ehsan Azin \& Hamid Moghimi \\ Microbial Technology and Products Research Center, University of Tehran, Tehran, Iran \\ Correspondent author: hmoghimi@ut.ac.ir
}

\begin{abstract}
The extensive application of dyes in the textile industries and their discharge in the wastewaters leads to numerous environmental pollutions; therefore, treating these wastewaters by efficient and eco-friendly methods is a necessity. In this study, potent strains were isolated by the enrichment technique according to their maximum dye sorption at the lowest possible time at $500 \mathrm{~nm}$. Consequently, the best isolate was selected and the dye removal was investigated in different concentrations of Congo red. Therefore, 50 different fungal strains were isolated in this study, of which 10 were able to dye removal. According to the results, isolate ADH8 was selected as the best strain with $94 \%$ of dye sorption. Moreover, during 48 hours, $80 \%$ of dye content was removed at all dye concentrations by this isolate, and the most growth rate and dye removal was achieved at $1000 \mathrm{mg} / \mathrm{l}$. The results showed that different salt concentrations have no effect on dye sorption of the selected isolate. Molecular identification of ADH8 revealed that this isolate have a 100\% similarity to Mucor circinelloides which was deposited under the accession number of UTMC5032 in the University of Tehran Microorganisms Collection. The results obtained from the dye removal of textile wastewater showed that the most amount of dye sorption by M. circinelloides UTMC5032 was 35-60\% during three hours of biomass treatment as compared with the control sample. The obtained results indicated that, M. circinelloides UTMC5032 is highly capable in azo dyes sorption and could be utilized in the biosorption of dye in the textile industries wastewaters for the first time.
\end{abstract}

Key words. biotreatment, dyeing effluents, isolation, myco-sorbent, screening

Received 24.04.2017/ Revised 04.04.2019/ Accepted 22.04.2019/ Published 21.11.2020

دريافت: د 
باشد. در روش جذب زيستى، رنگ موجود در يساب به گروههاى

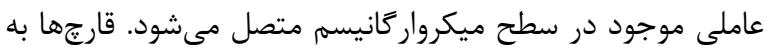

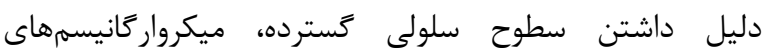

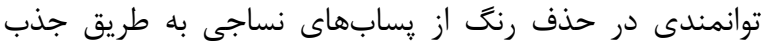

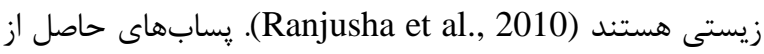

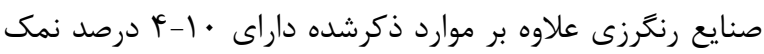

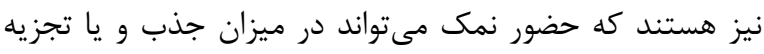

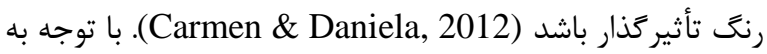

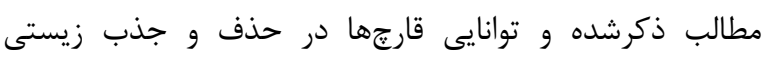

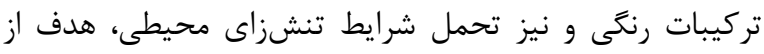

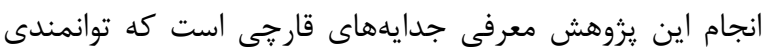
جذب رنغهاى آزو را دارا هستند.

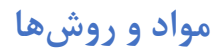

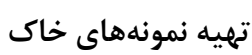
در اين مطالعه 9 نمونه خاك از نمونههاى شور و خاك خاك اطراف

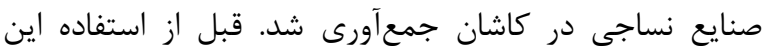

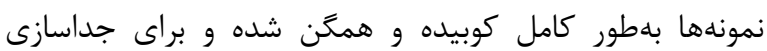
جدايههاى قارجى مورداستفاده قرار ترفت. محيط كشت و شرايط رشد

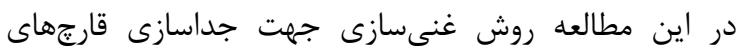

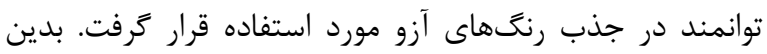

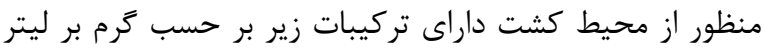

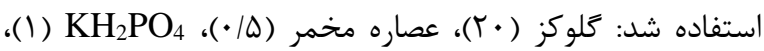
$\mathrm{Na}_{2} \mathrm{HPO}_{4}$ ،(・/・1) $\mathrm{FeSO}_{4} .7 \mathrm{H}_{2} \mathrm{O}$ ،(・/Q) $\mathrm{MgSO}_{4} \cdot \mathrm{H}_{2} \mathrm{O}$ (*/・1) $\quad \mathrm{CaCl}_{2} \quad(\cdot / \cdot \cdot 1) \quad \mathrm{ZnSO}_{4} .7 \mathrm{H}_{2} \mathrm{O} \quad(\cdot / \cdot \Delta)$ ري

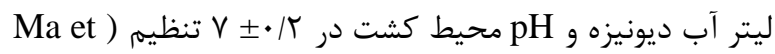

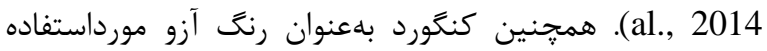

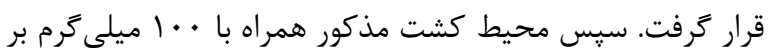

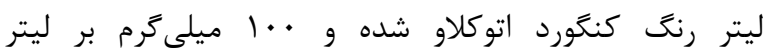

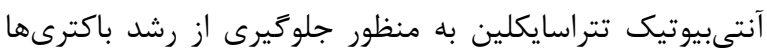

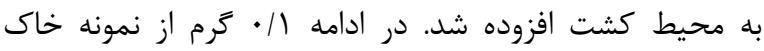

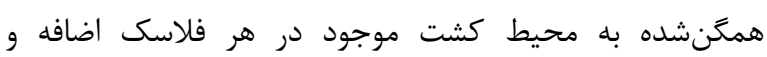

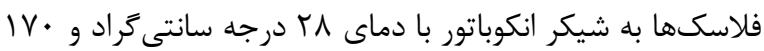

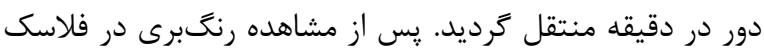

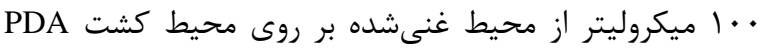

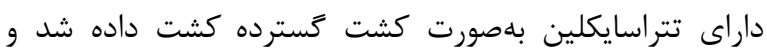

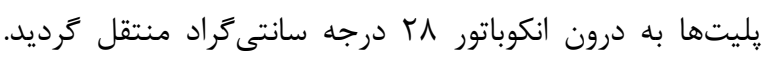

مقلهمه

در حال حاضر بيش از صد هزار نوع رنت بلهصورت تجارى

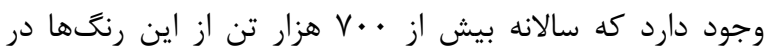

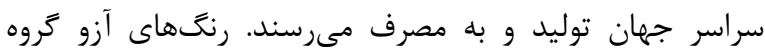
بزرگى از رنغهاى مصنوعى بوده كه در صنايع مختلف از قبيل

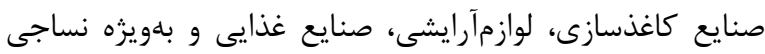

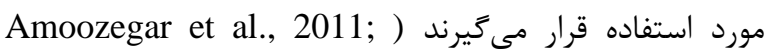
Sivasamy \& Sundarabal 2011; Taran, 2013 رنگها با بيوندهاى دوكانه ميان دو اتم نيتروزن خود شناخته مىشوند (Jafari et al., 2013; Almeida \& Corso, 2014)

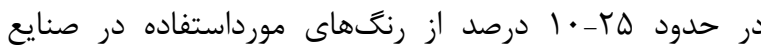

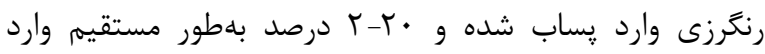

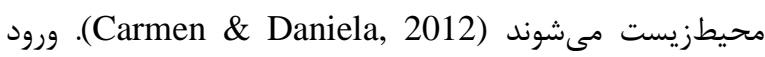
اين رنكها به محيطزيست علاوه بر جهره نازيبايى كه به محيط

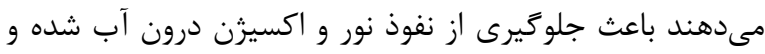

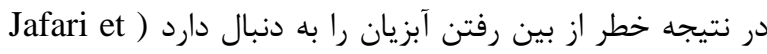
al., 2013, Wang et al., 2015

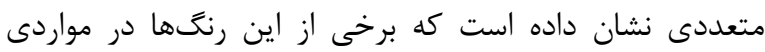

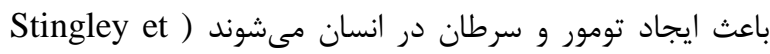

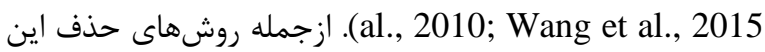
رنغَها از يسابهاى توليدى صنايع نساجى مىتوان به روشهاى

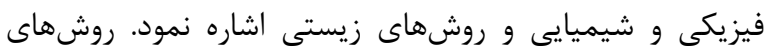

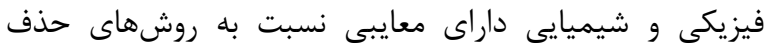
زيستى هستند كه مىتوان به هزينه بالاى تجهيزات و توليد

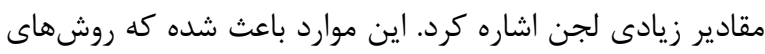

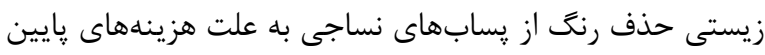

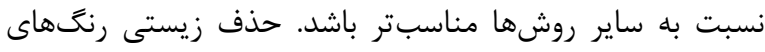

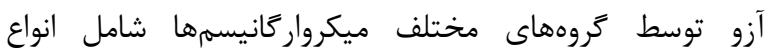

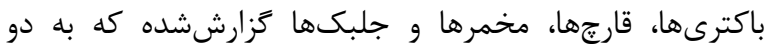

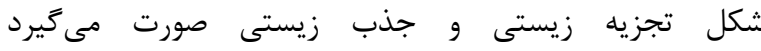
Sivasamy \& Sundarabal, 2011) ميكرواركانيسم، رنغ را از طريق آنزيمهاى اكسيدوردوكتازى

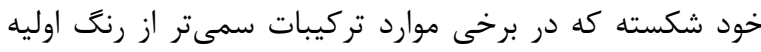

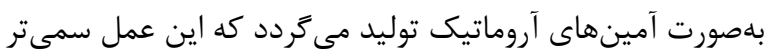
شدن يساب توليدى را در يى دارد (Katuri et al., 2009). روش جذب زيستى نسبت به تجزيه زيستى به دليل عدم توليد متابوليتهاى سمى و همجنين استفاده كسترده در شرايط زئس

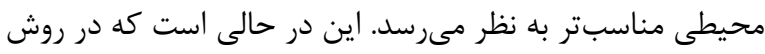

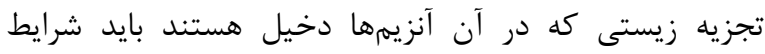

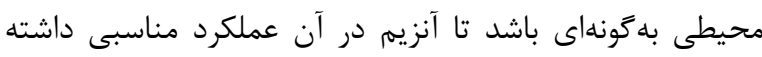


كرفت (Watanabe, 2010). جهت شناسايى سويه منتخب به

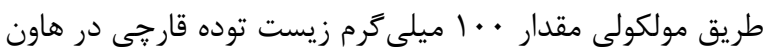

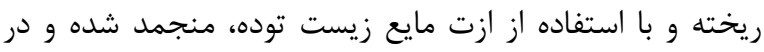
هاون كوبيده شد. استخراج DNA قارج با استفاده از روش فنلكلروفرم صورت كرفت (Sambrook \& Russell 2001).

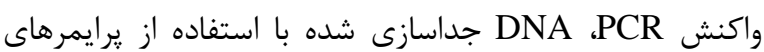
5'-TCC GTA GGT GAA CCT :ITS1) ITS4, ITS1 5'-TCC TCC GCT TAT TGA :ITS4, GCG G-3' (TAT GC-3' ماكروزن كره جنوبى تعيين توالى شده و نتيجه به دست آمده از

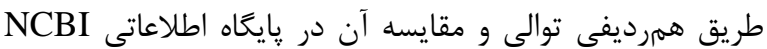
مورد بررسى قرار ترفت (Jafari et al., 2014). مقايسه ميزان جذب زيستى رنت توسط زيست توده تر و خشك 1032 M. circinelloides UTMC در اين مطالعه علاوه بر بررسى جذب رنى در محيط كشت، ميزان جذب رنغ توسط زيست توده تر و خشك در غلظت . .9 ميلى گرم بر ليتر رنگ محلول در آب مقطر مورد مقايسه قرار

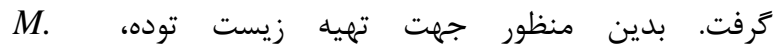
circinelloides UTMC 5032 كرديد و زيست توده توليدى يس از يك هفته با سانتريفوز با دور F... زيست توده جداشده سه بار با سرم فيزيولوزى شسته شد. جهت آر دهيط

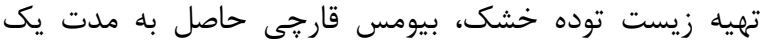

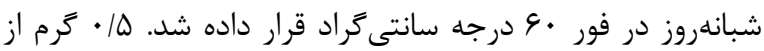

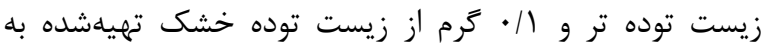

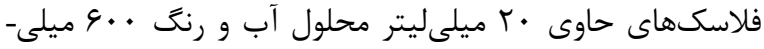

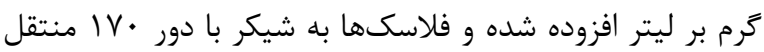

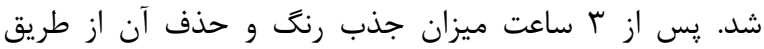

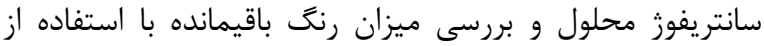

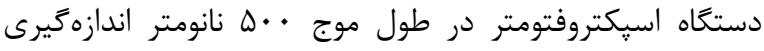

بر بـى ميزان جذب رنك 5032 از

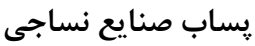

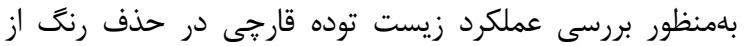

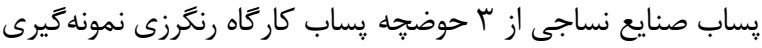

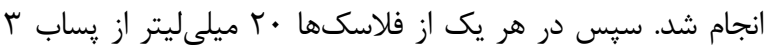

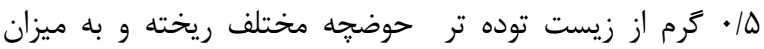
آمادهشه در مرحله قبل به هر يك از فلاسكهاى حاوى زئل

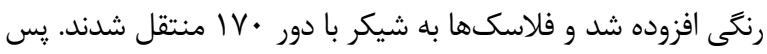
از r ساعت، يُابهاى تيمار شده با زيست توده، سانتريفوز شده و
يس از رشد قارجها در يليت جدايههاى قارجى حاصل بر روى محيط كشت PDA خالصسازى شد. انتخاب جدايه با بيشتر ين ميزان جذب رنى

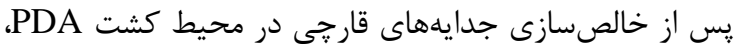

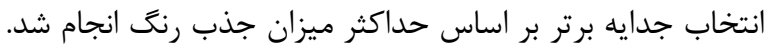

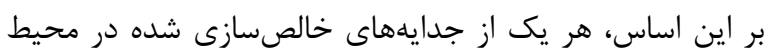

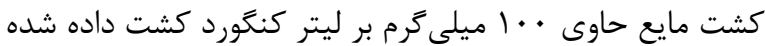

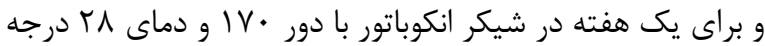

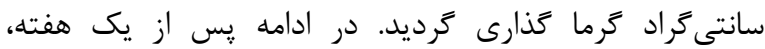

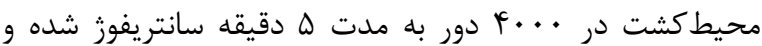

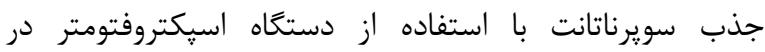
طولموج ·له نانومتر از طريق رابطه زير مورد بررسى قرار

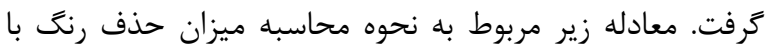
استفاده از خواندن جذب نمونه تيمار شده و نمونه شاهد را نشان

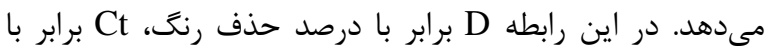

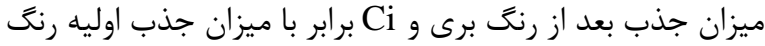

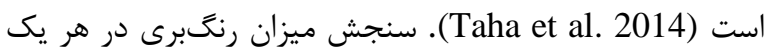

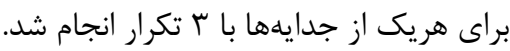

$$
\mathrm{D}=100\left(\frac{C i-C t}{C i}\right)
$$

معادله

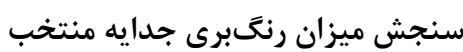
يس از انتخاب جدايه برتر از لحاظ ميزان جذب رئر رنت

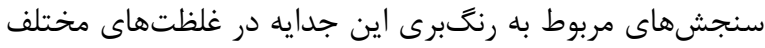

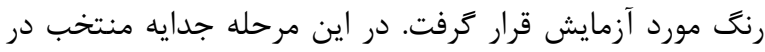

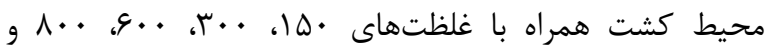

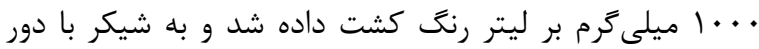
IV.

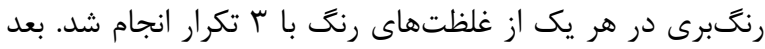

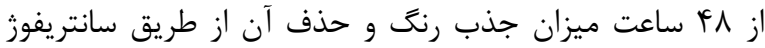

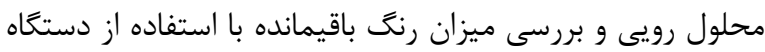

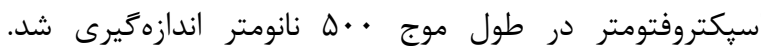
درنهايت ميزان زيست توده خشك توليد شده در محيطهاى

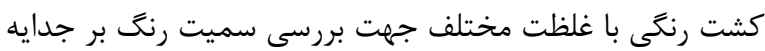

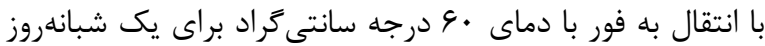

$$
\begin{aligned}
& \text { مورد وزن سنجى قرار كرفت. } \\
& \text { شناسايى سويه منتخب }
\end{aligned}
$$

بمنظور شناسايى قارج جداسازى شده با تهيه اسلايد كالجر و و

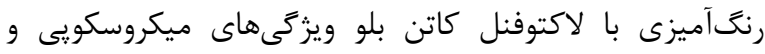

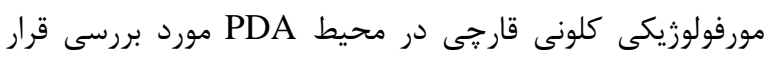




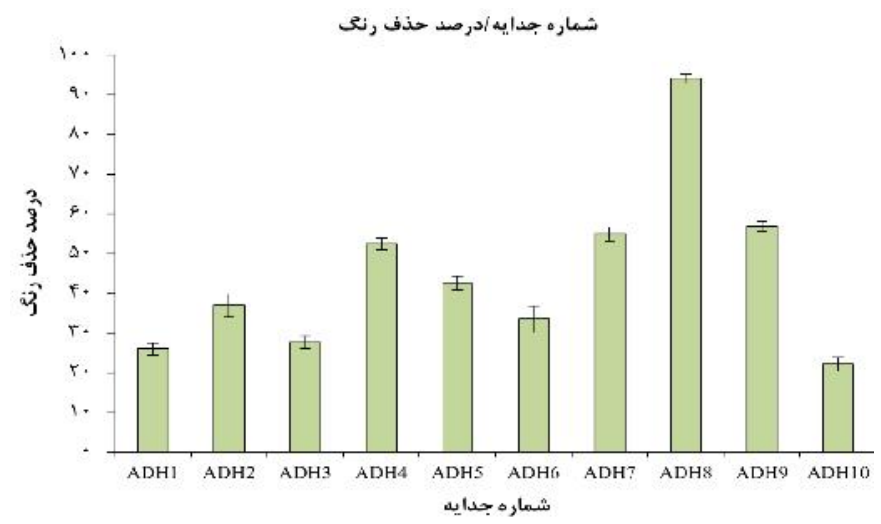

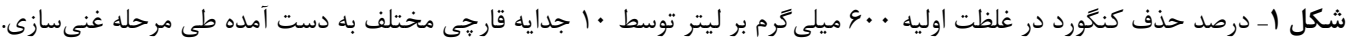

Fig. 1. Congo red removal percentage at initial concentration of $600 \mathrm{mg} / \mathrm{l}$ by 10 fungal isolates obtained during the enrichment step.

مراحل بعدى آزمايش در دماى † درجه سانتى

$$
\text { شدند. }
$$

انتخاب جدايه با بيشترين ميزان جذب رنت

بررسى توانايى هر يك از جدايههاى به دست آمده در حذف بئن

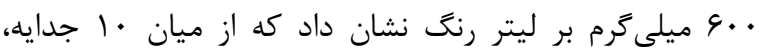
جدايه شماره ADH8 با Fو درص درم حذف رنغ بيشترين ميزان جذب رنت را دارا است (شكل ()). بر اساس نتايج ارائه شده در

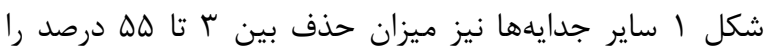
نشان دادند. جدايه ADH8 به عنوان جدايه برتر براى ادامه

$$
\text { برسىها انتخاب شد. }
$$

\section{سنجش ميزان رنتَبرى جدايه منتخب}

بررسىهاى انجامگرفته در مورد ميزان و زمان جذب جنب جدايه

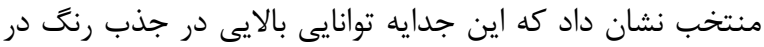

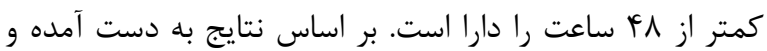
بررسىهاى آمارى نشان داده شد كه حضور غلظتهاى مختلف

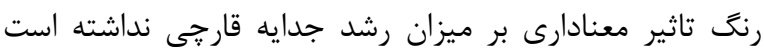

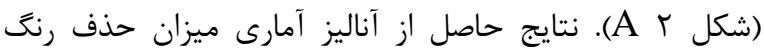

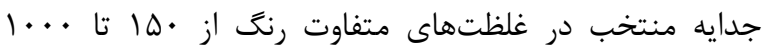
ميلى

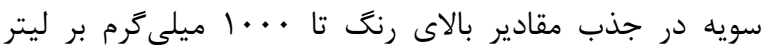

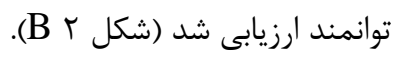
شناسايى جدايه منتخب

بررسىهاى ريختشناسى كلنى پِنبهاى شكل در محيط PDA و

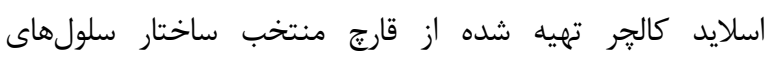
سنئوسيتى همراه با اسيورانزيوم، اسيورانزيوسيور و كلوملاى متورم

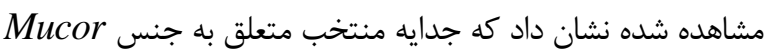
است. شناسايى مولكولى اين قارج با استفاده از يرايمرهاى

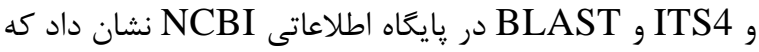

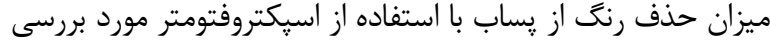
قرار گرفت. جهت بررسى ميزان حذف رنغ، جذب نور يساب مورد

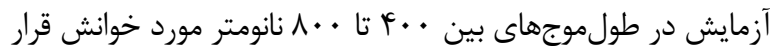
كرفت و با جذب نمونه شاهد مورد مقايسه قرار گرفت ( Almeida

. (\& Corso, 2014

M. اثر NaCl بر ميزان جذب زيستى رنت توسط circinelloides UTMC 5032

در اين مرحله به منظور ارزيابى اثر نمك بر ميزان جذب رنت

M. circinelloides UTMC 5032 توسط زيست توده تر ميز

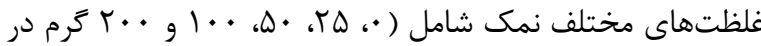
ليتر) از NaCl مورد بررسى قرار گرفت. بدين منظور فلاسكهاى

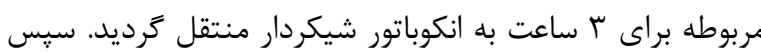
هر يك از نمونهها سانتريفوز و جذب آنها با استفاده از دستگاه

$$
\text { آناليز آمتروفتومتر مورد سنجش قرار گرفت. }
$$

نتايج و اطلاعات به دست آمده در مراحل مختلف، بوسيله نرم

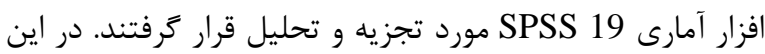

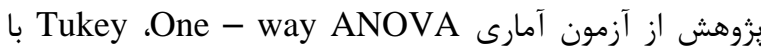
ضريب اطمينان ه9 درصد استفاده شده و سطح معنادارى نتايج

$$
\text { به صورت P } \text { حزارش شد. }
$$

\section{نتابج} جداسازى و خالصسازى جدايdهاى قارجى مختلف

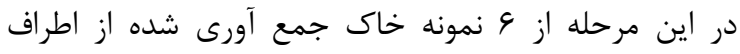

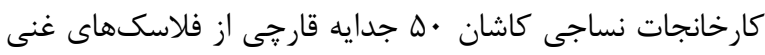
سازى جداسازى بهدست آمد كه • ا جدايه قارجى مختلف داراى توانايى رنَّبرى با ويزَّى هاى ريختشناسى متفاوت در محيط خالص سازى شد. جدايههاى قارجى به منظور انجام 

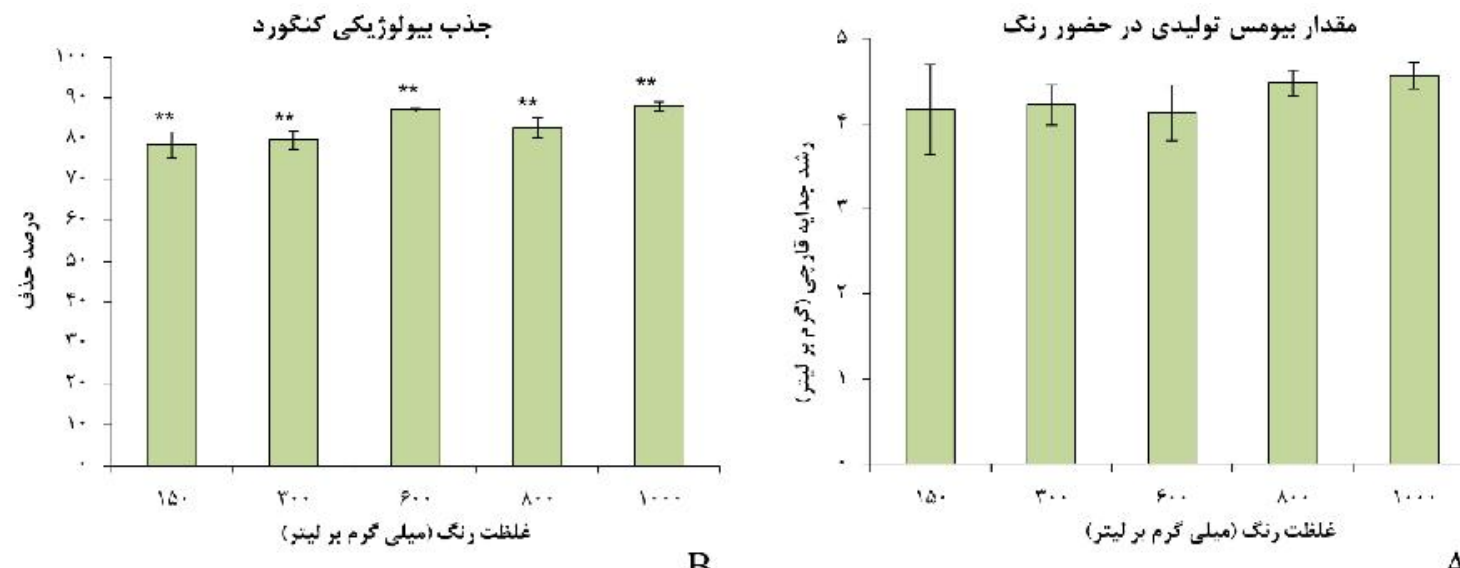

شكل r- A ميزان زيست توده قار جى توليدشده در غلظتهاى مختلف كنكَورد. B. درصد جذب كنَّورد توسط جدايه منتخب قارجى در غلظتهاى مختلف

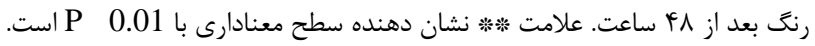

Fig. 2. A. Amount of fungal biomass produced in different concentrations of Congo red. B. Adsorption percentage of Congo red by selected fungal isolate at different dye concentrations after 48 hours. $* *=\mathrm{P} \leq 0.01$.

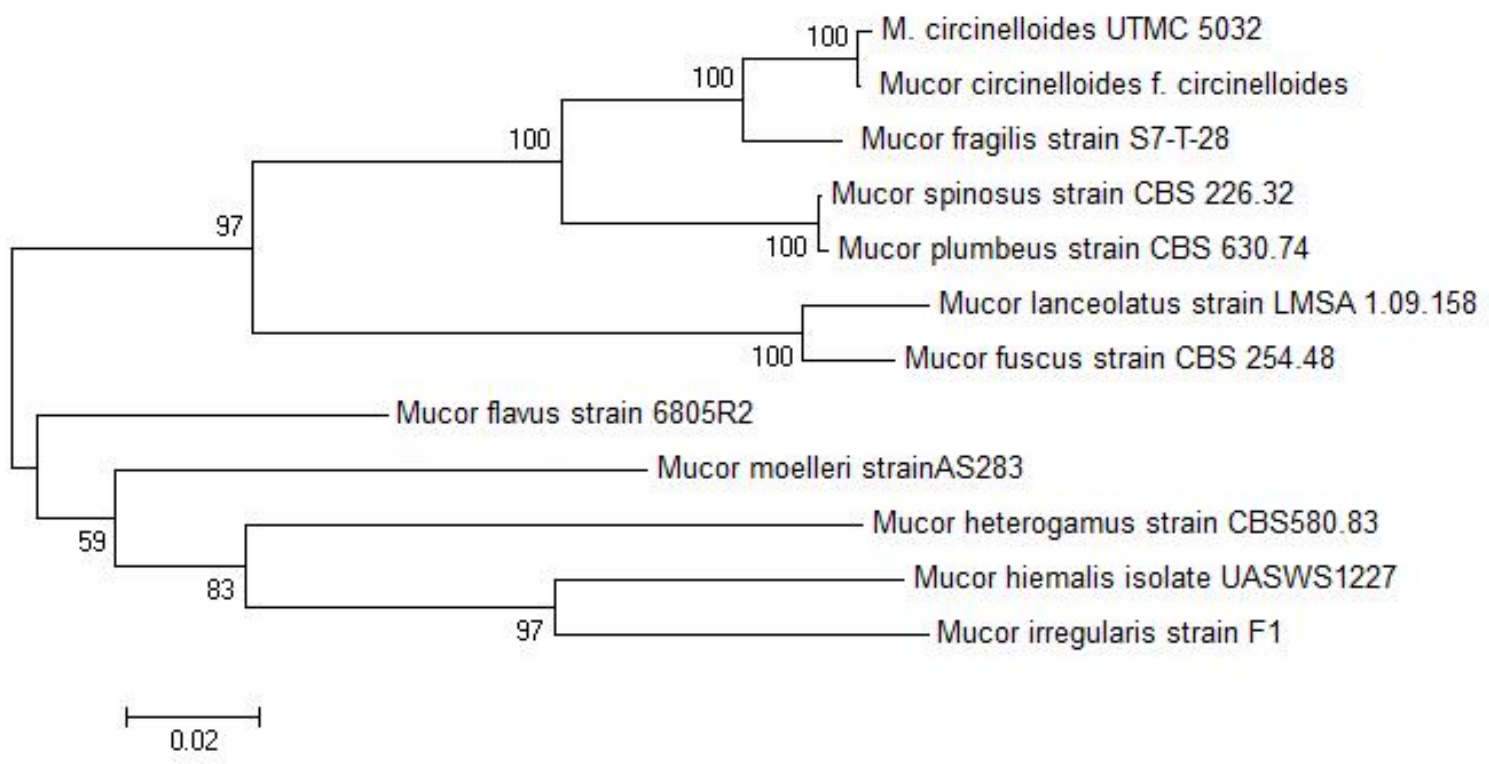

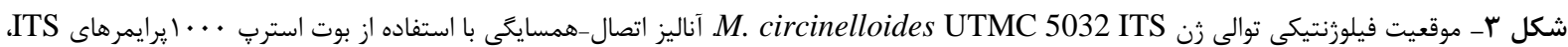

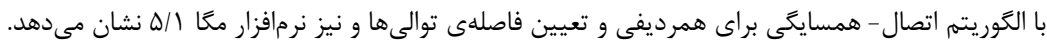

Fig. 3. Phylogenetic position of partial ITS gene from M. circinelloides UTMC 5032. Neighbor-joining analysis using 1000 bootstrap replicates was used to infer tree topology by MEGA 5.1.

\section{M. circinelloides مقايسه ميزان جذب زيست توده تر و خشك در} UTMC 5032

بررسىهاى انجامگرفته جهت مقايسه ميان جذب زيستى رنت توسط زيست توده تر و زيست توده خشك نشان داد مكانيسم جذب

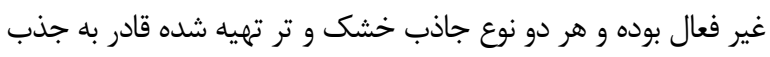
زيستى رنى هستند. براساس نتايج به دست آمده (شكل عأ و جدول

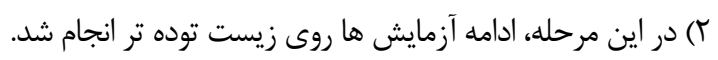

Mucor circinelloides متوده و با كد זr. ADH8 در كلكسيون ميكرواركانيسمهاى دانشخاه تهران ثبت و نتمهدارى

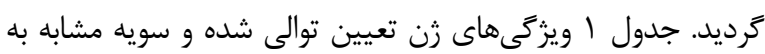

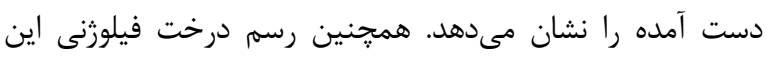
M. بيشترين نشان داد كه circinelloides 


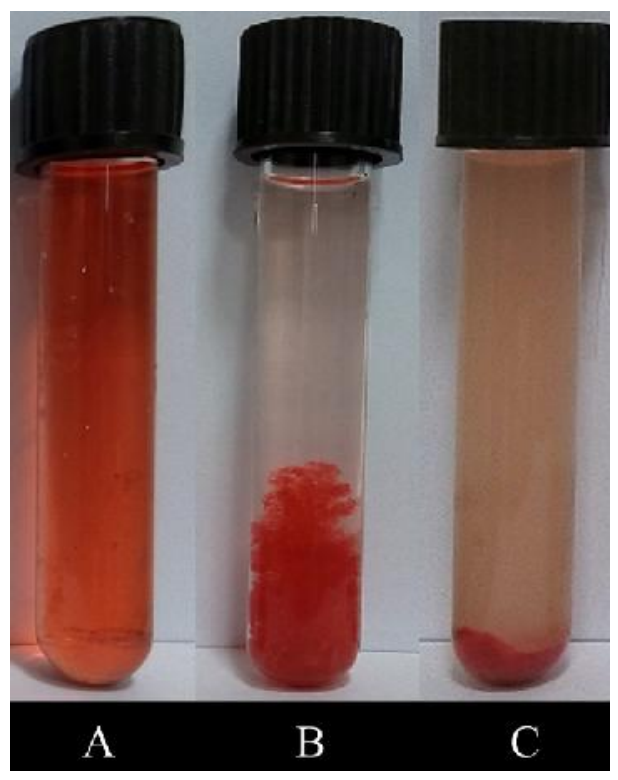

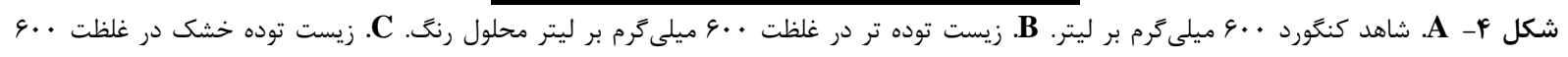

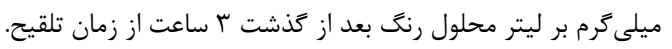

Fig. 4. A. Congo red control, $600 \mathrm{mg} / \mathrm{l}$. B. wet biomass at $600 \mathrm{mg} / \mathrm{l}$ dye solution. C. dry biomass at $600 \mathrm{mg} / \mathrm{l} \mathrm{dye}$ solution after $3 \mathrm{~h}$ from inoculation.

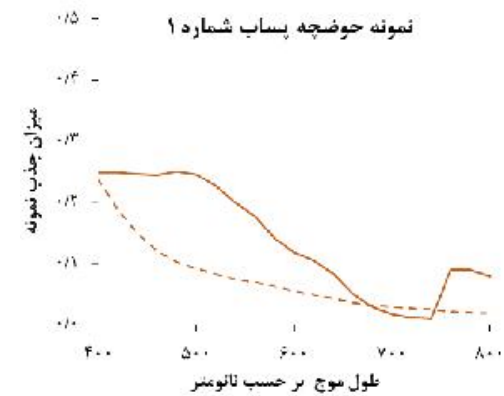

$\Lambda$

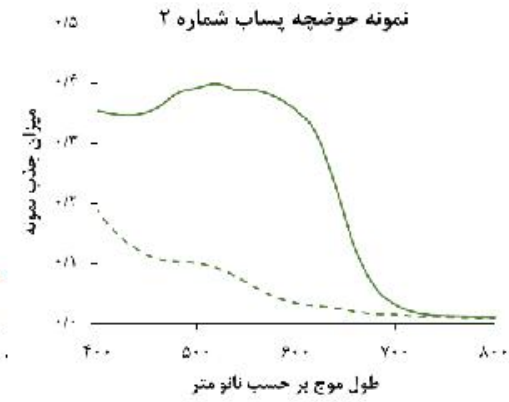

B

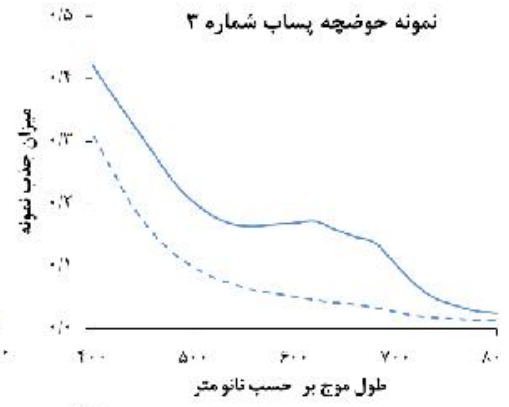

C

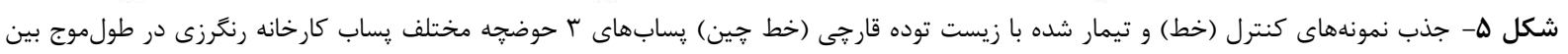

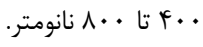

Fig. 5. Absorbance of controls (lines) and fungal biomass treated wastewater (dashes) of three different textile wastewater ponds in 400-800 $\mathrm{nm}$.

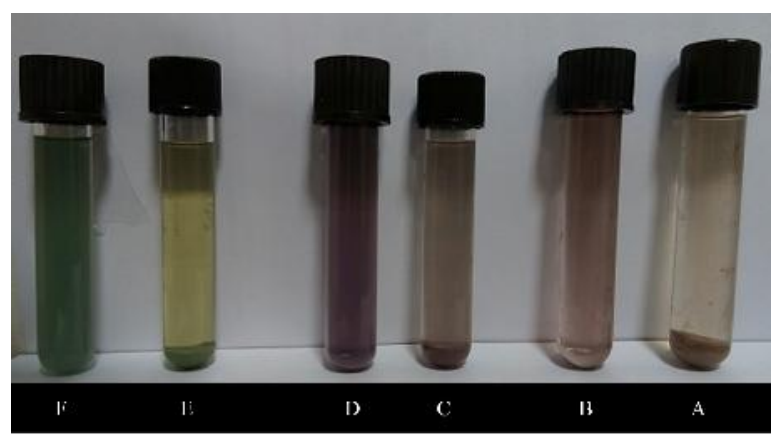

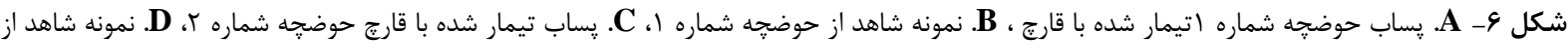

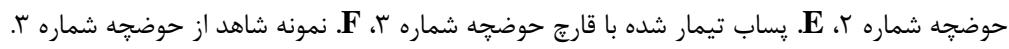

Fig. 6. A. Pond 1 treated wastewater with the fungal isolates. B. Pond 1control sample. C. Pond 2 treated wastewater with the fungal isolates. D. Pond 2 control sample. E. Pond 3 treated wastewater with the fungal isolates. F. Pond 3 control sample. 


\section{درصد جذب رنى/درصد نمك}

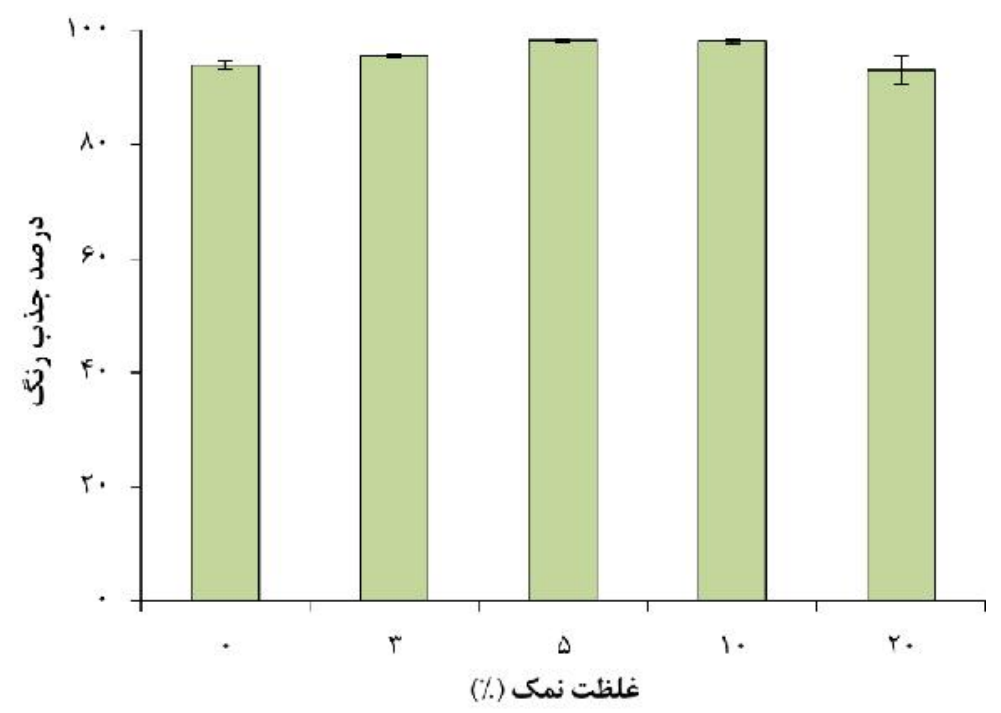

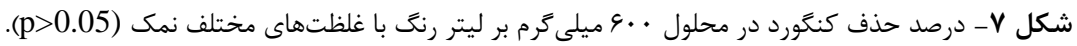

Fig. 7. Congo red removal percentage at $600 \mathrm{mg} / \mathrm{l}$ dye solution with different salt concentrations (p>0.05).

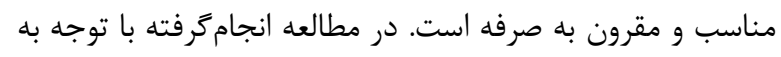
M. UTMC نتايج به دست آمده نشان داده شد كه سويه 5032 circinelloides

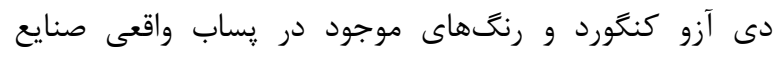

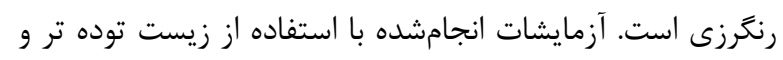

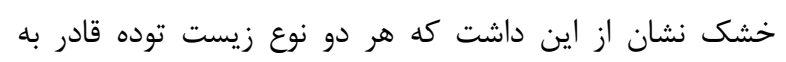

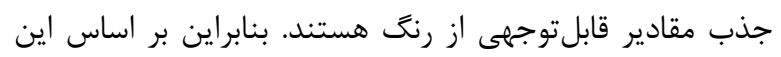

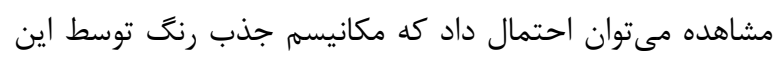

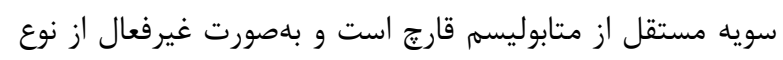
جذب زيستى سطحى است (Singh 2015). قارجها به دليل دارا

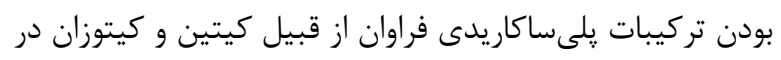

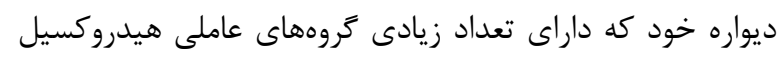

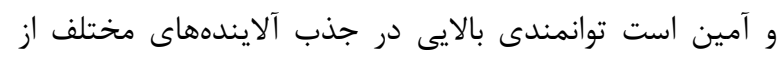

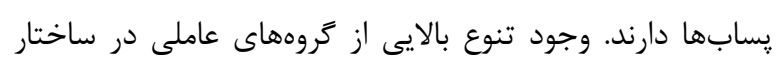

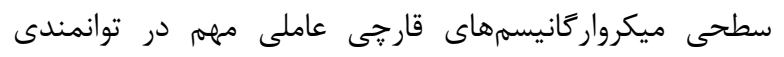

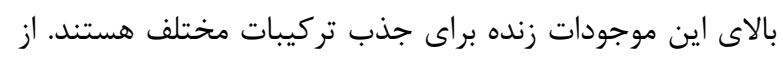

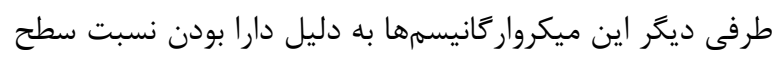

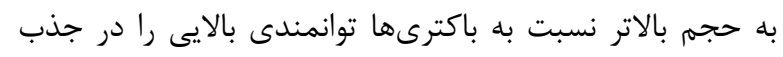

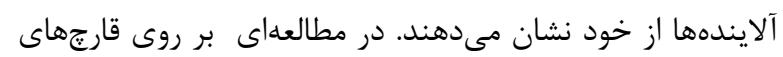
غلطي

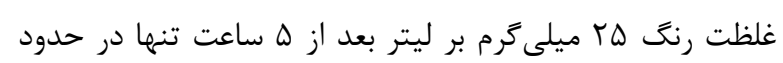

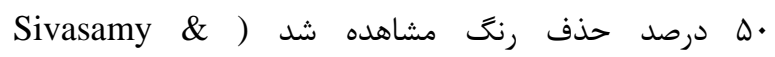

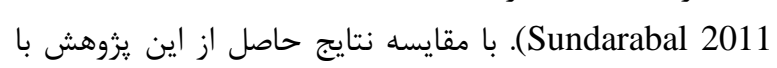
UTMC نتايج مطالعات ييشين مىتوان نتيجه كرفت كه 5032
بررسى جذب رنغ جدايه قارجى از يساب واقعى صنايع رنغرزى

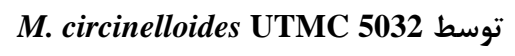

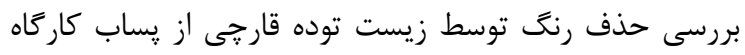

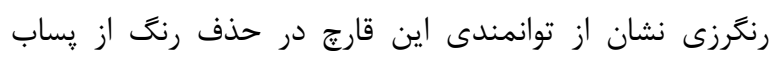

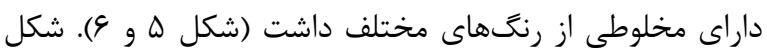

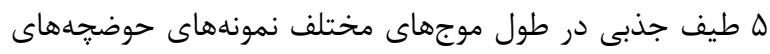

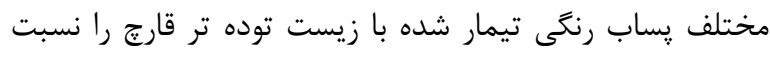

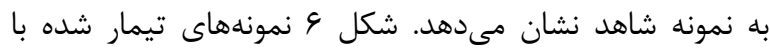

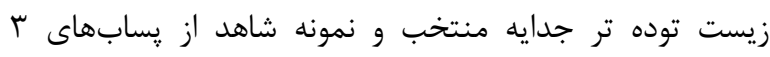

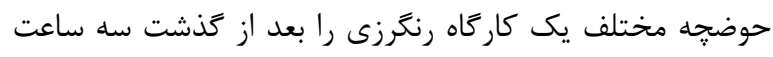

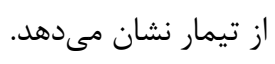

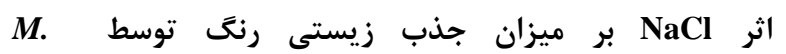
circinelloides UTMC 5032

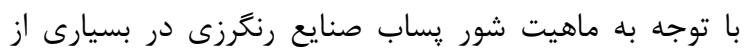

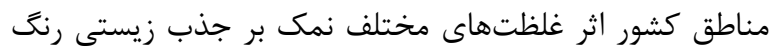

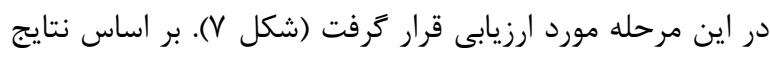

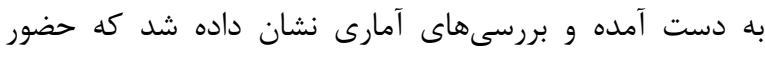

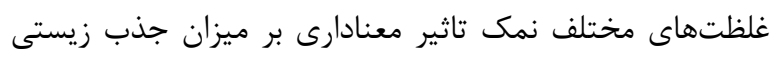
رنى نسبت به نمونه شاهد نداشته است (p) (p).05).

بحث

امروزه افزايش توليد پِابهاى رنكى صنايع نساجى به عنوان

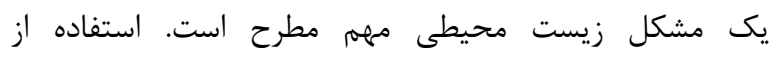

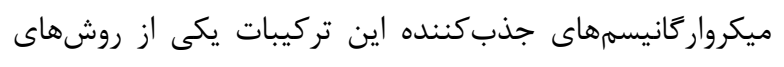


قارجى به دليل سطح جذب بالا و دارا بودن يليمرهاى زيستى با توان جذب بالا در ساختار ديواره خود، بسيار حائز اهيمت است.

\section{سياسگزارى}

از كليه يزوهشكران آزمايشكاه بيوتكنولوزى محيطى دانشخاه

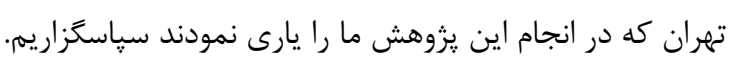

\section{REFERENCES}

Ali, N., Hameed, A. \& Ahmed, S. 2009. Physicochemical characterization and Bioremediation perspective of textile effluent, dyes and metals by indigenous Bacteria. Journal of Hazardous Materials 164: 322-328.

Almeida, E. \& Corso, C. 2014. Comparative study of toxicity of azo dye Procion Red MX-5B following biosorption and biodegradation treatments with the fungi Aspergillus niger and Aspergillus terreus. Chemosphere 112: 317-322.

Amoozegar, M.A., Hajighasemi, M., Hamedi, J., Asad, S. \& Ventosa, A. 2011. Azo dye decolorization by halophilic and halotolerant microorganisms. Annals of Microbiology 61: 217-230.

Carmen, Z. \& Daniela, S. 2012. Textile organic dyescharacteristics, polluting effects and separation/elimination procedures from industrial effluents-a critical overview. Organic Pollutants Ten Years After the Stockholm Convention-Environmental and Analytical Update, InTech: Croatia 55-86.

Jafari, N., Kermanshai, R.K. \& Soudi, M.R. 2013. Screening, identification and optimization of a yeast strain, Candida palmioleophila JKS4, capable of azo dye decolorization. Iranian Journal of Microbiology 5: 434440.

Jafari, N., Soudi, M.R. \& Kasra-Kermanshahi, R. 2014. Biodecolorization of textile azo dyes by isolated yeast from activated sludge: Issatchenkia orientalis JKS6. Annals of Microbiology 64: 475-482.

Katuri, K.P., Mohan, S.V., Sridhar, S., Pati, B. \& Sarma, P. 2009. Laccase-membrane reactors for decolorization of an acid azo dye in aqueous phase: process optimization. Water Research 43: 3647-3658.

Ma, L., Zhuo, R., Liu, H., Yu, D., Jiang, M., Zhang, X. \& Yang, Y. 2014. Efficient decolorization and detoxification of the sulfonated azo dye Reactive Orange 16 and simulated textile wastewater containing Reactive Orange 16 by the white-rot fungus Ganoderma sp. En3 isolated from the forest of Tzu-chin Mountain in China. Biochemical Engineering Journal 82: 1-9.

Ranjusha, V., Pundir, R., Kumar, K., Dastidar, M. \& Sreekrishnan, T. 2010. Biosorption of Remazol Black B dye (Azo dye) by the growing Aspergillus flavus. Journal of Environmental Science and Health, Part A 45: 1256-1263.

Sambrook, J. \& Russell, D. W. 2001. Molecular cloning: a laboratory manual. Cold Spring Harbor Laboratory Press, Cold Spring Harbor, New York. 559-562.

Singh, S. N. 2015. Microbial degradation of synthetic dyes in wastewaters, Springer. pp: 2-6.
M. circinelloides حذف درصد بالايى از غلظت رنت طى مدت زمان كمترى است. مقادير زيست توده توليدى در غلظتهاى مختلف رنت رنى نشان داد كه غلظتهاى بالاى رنت بر روى اين قارج سمى نبوده و سويه

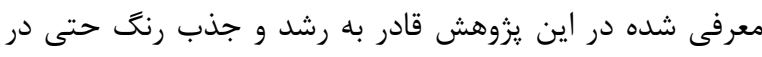

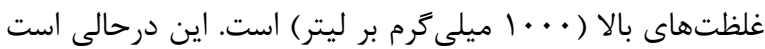
كه به طور متوسط ميزان غلظت رنت در رِاب صنايع نساجى و

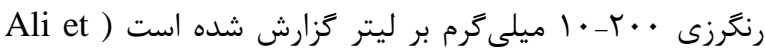

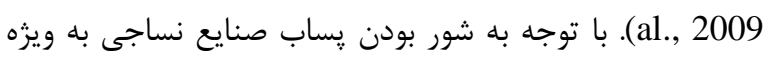

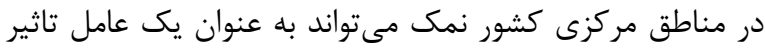

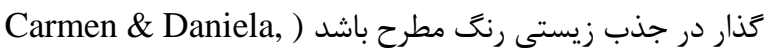

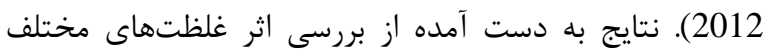

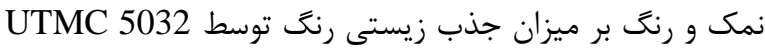
M. circinelloides توسط اين سويه نداشته و مىتوان از اين سويه در حذف زيستى رنت از يساب شور صنايع نساجى استفاده كرد.

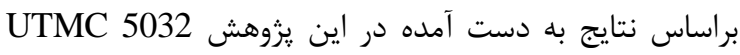
M. circinelloides و توانمند در جذب رنتهاى آزو از رِابهاى كارخانجات بهات نساجى

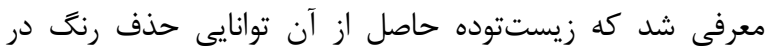

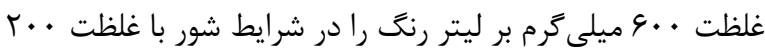

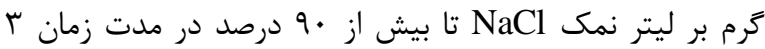
ساعت دارا است. با توجه به توانمندى اين سويه در جذب رنغ رئهاى

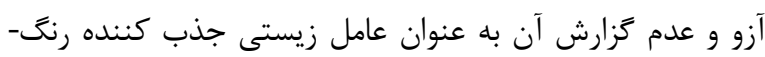

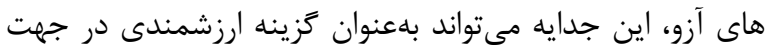
جذب رنت از رِابهاى صنايع نساجى معرفى شود.

$$
\text { نتيجه تيرى }
$$

وجود نمك در گُساب صنايع نساجى موجب شده است كه

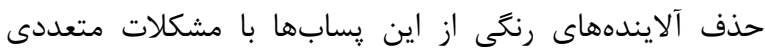

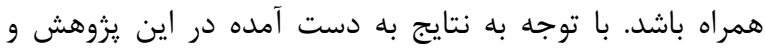

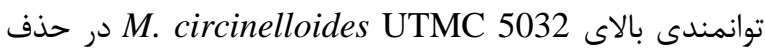
كنگُورد از محلول آبى و همجنين تركيبات رنكى موجود در يسابهاى واقعى، استفاده از جاذبهاى قارجى مى هوتواند راهكارى مناسب در جهت حذف آلايندهها از يساب صنايع نساجى باشد.

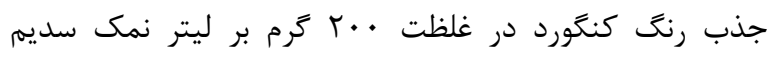
كلريد نشان دهنده عدم تداخل نمك در جذب رنت توسط جاذب زيستى 5032 circinelloides UTMC توجه به اين نتايج، جداسازى و شناسايى جاذبهاى جديد 
Sivasamy, A. \& Sundarabal, N. 2011. Biosorption of an azo dye by Aspergillus niger and Trichoderma sp. fungal biomasses. Current Microbiology 62: 351-357.

Stingley, R.L., Zou, W., Heinze, T.M., Chen, H. \& Cerniglia, C.E. 2010. Metabolism of azo dyes by human skin microbiota. Journal of Medical Microbiology 59: 108-114.

Taran, M. 2013. Decolorization of Remazol Black-B by Halomonas sp. PTCC1417 isolated from Urmia lake: Optimization by Taguchi methodology. Biological Journal of Microorganism 6: 1-10.

Taha, M., Adetutu, E., Shahsavari, E., Smith, A. \& Ball, A. 2014. Azo and anthraquinone dye mixture decolourization at elevated temperature and concentration by a newly isolated thermophilic fungus, Thermomucor indicae-seudaticae. Journal of Environmental Chemical Engineering 2: 415-423.

Wang, M.X., Zhang, Q.L. \& Yao, S.J. 2015 A novel biosorbent formed of marine-derived Penicillium janthinellum mycelial pellets for removing dyes from dye-containing wastewater. Chemical Engineering Journal 259: 837-844.

Watanabe, T. 2010. Pictorial atlas of soil and seed fungi: morphologies of cultured fungi and key to species. CRC press, 119-124.

How to cite this article:

Azin, E. \& Moghimi, H. 2020. Biosorption of congo red azo dye and decolorization of textile industry wastewater by fungus Mucor circinelloides UTMC 5032. Nova Bioloica Reperta 7: 322-330. (In Persian).

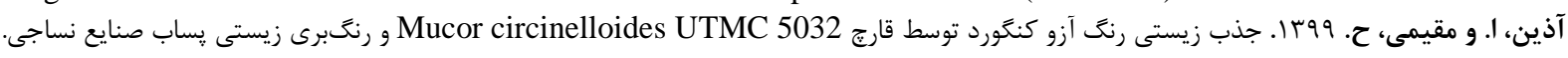

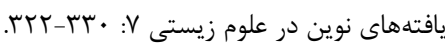

